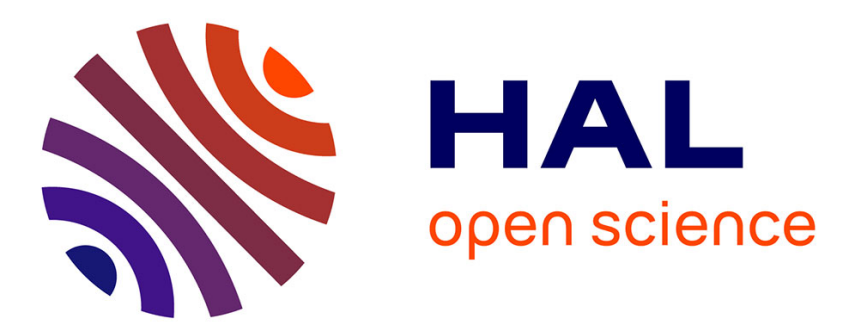

\title{
Animal welfare: towards transdisciplinarity - The European experience
}

\author{
Isabelle Veissier, Mara Miele
}

\section{To cite this version:}

Isabelle Veissier, Mara Miele. Animal welfare: towards transdisciplinarity - The European experience. Joint ISNH / ISRP International Conference 2014, Sep 2014, Canberra, Australia. 45 diapositives. hal-02738606

\section{HAL Id: hal-02738606 https://hal.inrae.fr/hal-02738606}

Submitted on 2 Jun 2020

HAL is a multi-disciplinary open access archive for the deposit and dissemination of scientific research documents, whether they are published or not. The documents may come from teaching and research institutions in France or abroad, or from public or private research centers.
L'archive ouverte pluridisciplinaire HAL, est destinée au dépôt et à la diffusion de documents scientifiques de niveau recherche, publiés ou non, émanant des établissements d'enseignement et de recherche français ou étrangers, des laboratoires publics ou privés. 


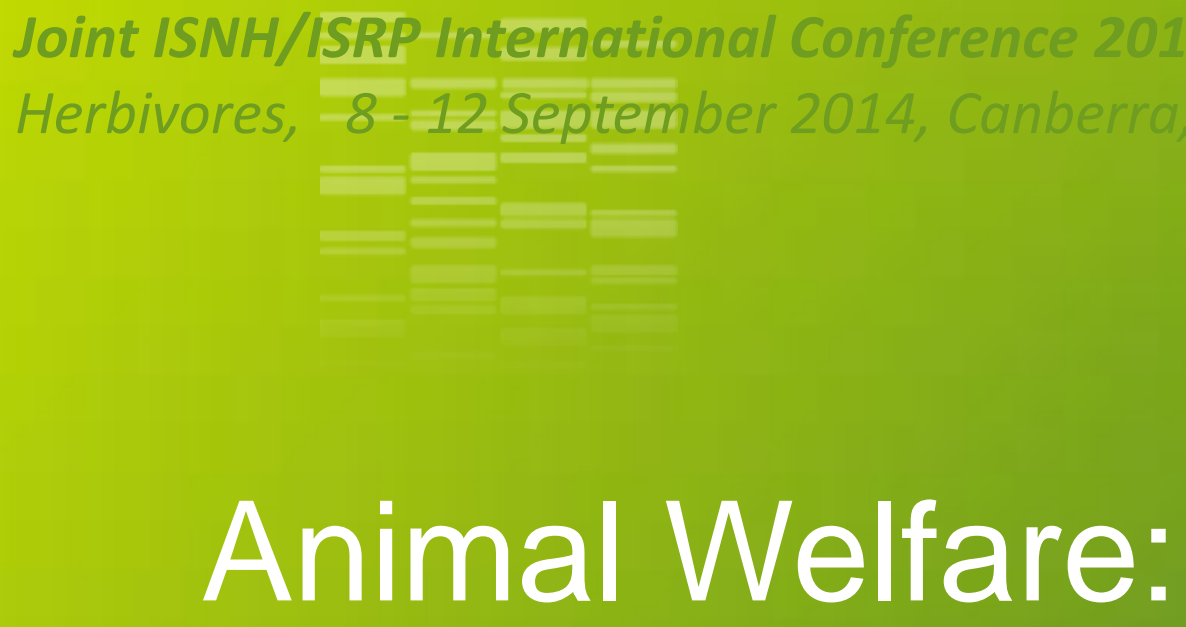 Towards transdisciplinarity}

Isabelle VEISSIER - Mara MIELE
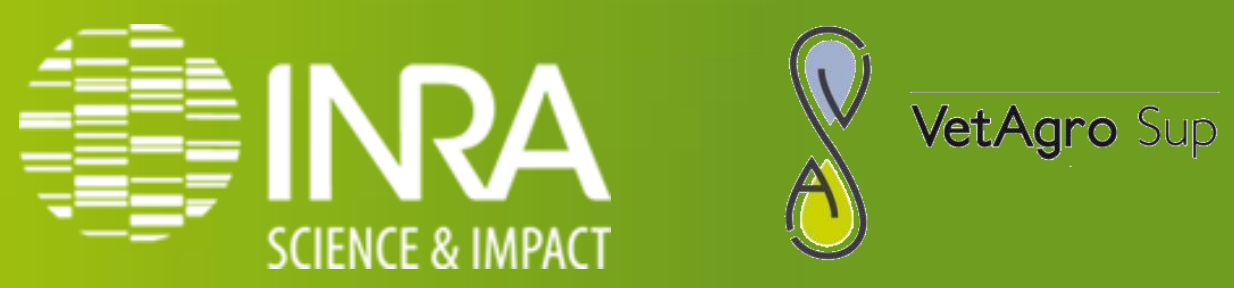


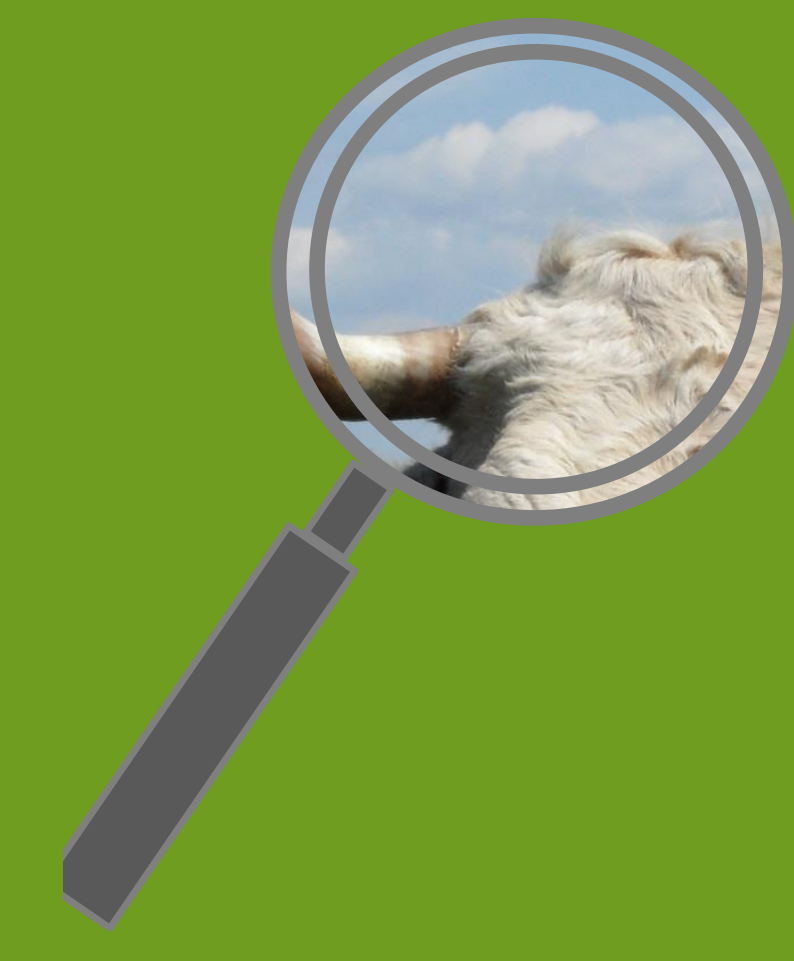




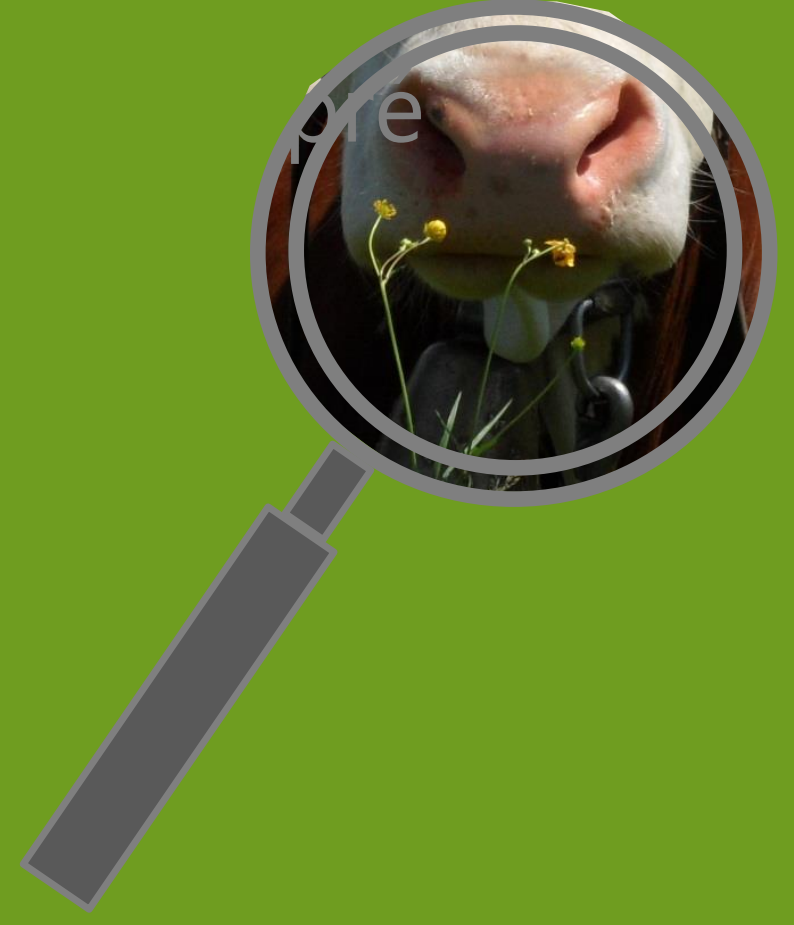




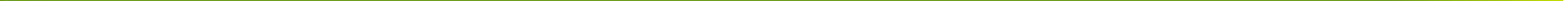




\section{Purpose of this talk}

A single point of view is not enough to understand animal welfare

Welfare is a wide term that embraces both the physical and

mental well-being of the animal (Brambell report 1965)

$>$ Animal welfare is a complex object:

It includes not only adaptation but also perception

$>$ Its study requires knowledge and methods

from several scientific disciplines

$>$ It is best understood by multidisciplinary approaches

A brief history of animal welfare science(s) will show how studies carried within the framework of unique disciplines progressively evolved into multidisciplinary research. 


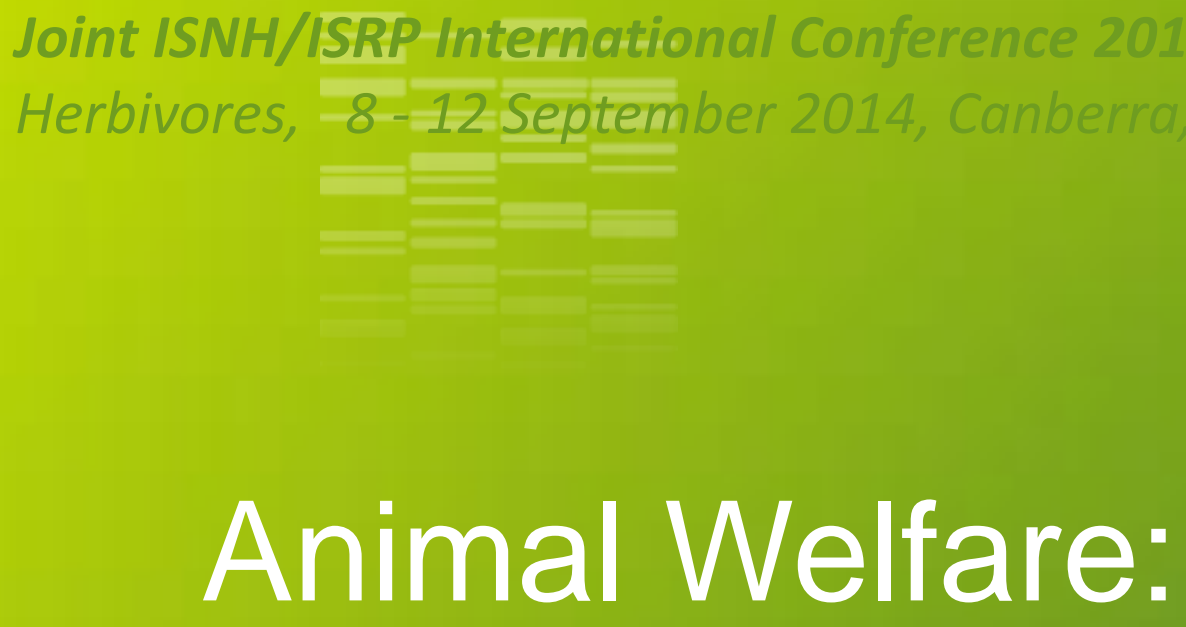 Towards transdisciplinarity}

Isabelle VEISSIER - Mara MIELE
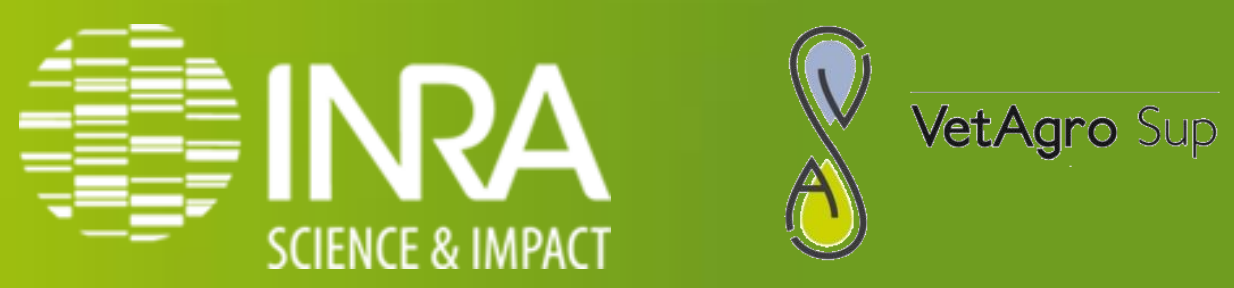
Early studies: separate disciplines, animal welfare not directly addressed

Animal welfare becoming an object of research use of methods previously designed for other purposes

\section{אิ?}

Bridging disciplines to understand animal affects

Interdisciplinary approach to develop a welfare assessment system

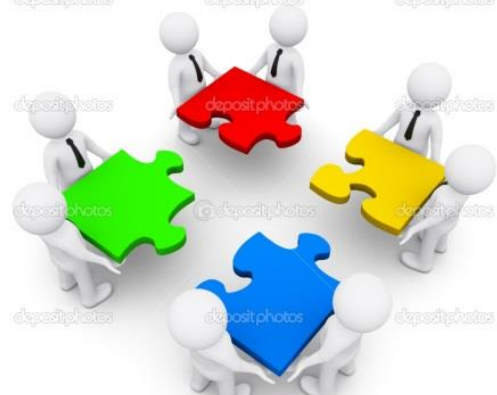

Next step: Transdiciplinarity to address facts $\&$ values

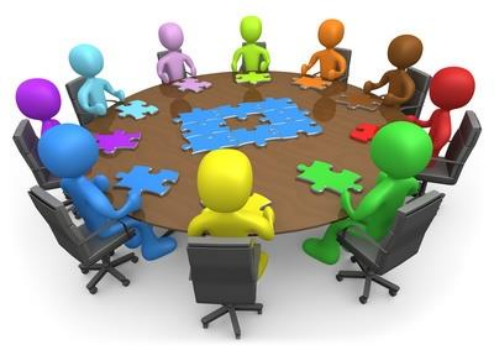


EARLY STUDIES

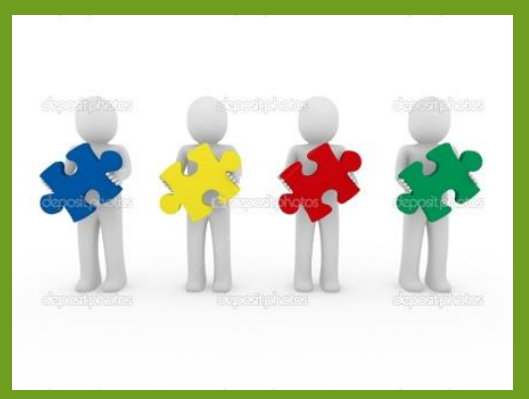

several disciplines,

animal welfare not directly addressed 


\section{Philosophy: the moral status of animals}

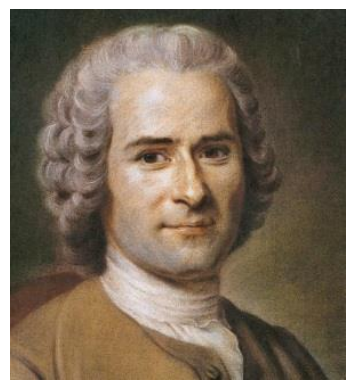

Rousseau, Bentham (18 $\left.{ }^{\text {th }}\right)$ : Animals are sentient and this confers them a moral consideration

The question is not, can they reason?, nor Can they talk?, but, Can they suffer? (Bentham 1781)

$>$ We should treat animals according to their ability to suffer

Still what affects the animals could feel was not defined 


\section{Physiology: stress syndrome}

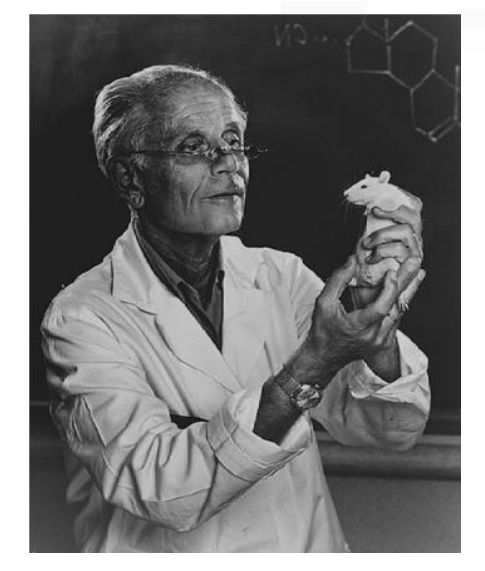

(Selye 1936)

electric shocks

cold

infections ...

00 adrenals hypertrophy
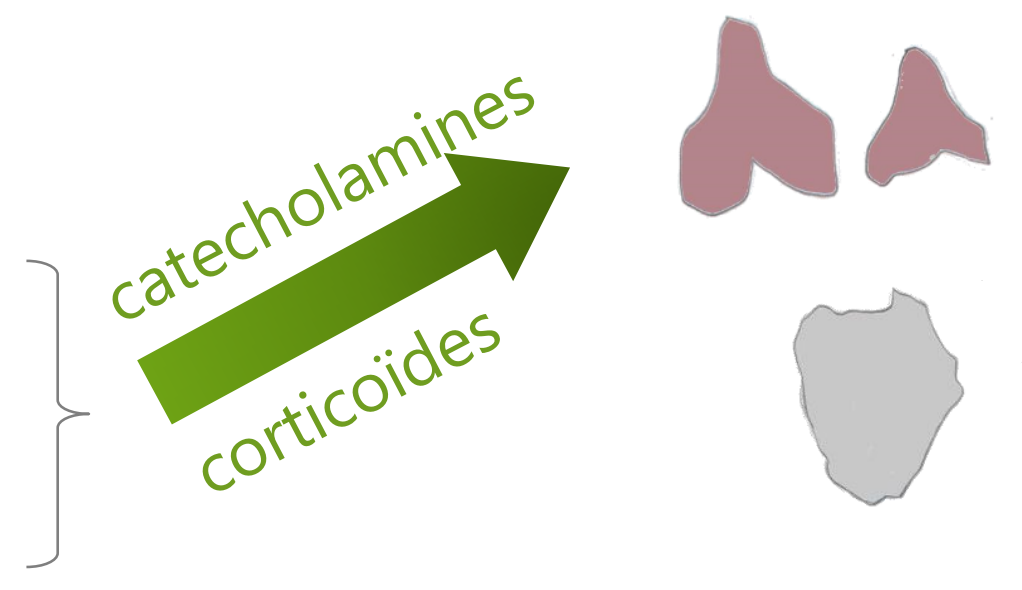

thymus atrophy

Stress: unspecific response of the body to an aggression that helps restore homeostasis.

No mention of how the aggression is perceived 


\section{Psychology: behaviourism}

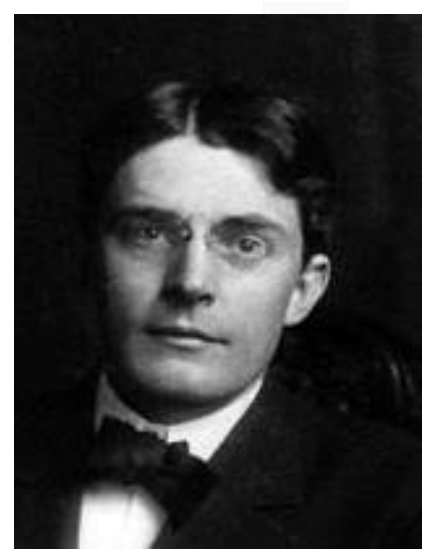

Watson (1913): new approach of psychology based on observable events

stimulus $\longrightarrow$ Black-box $\longrightarrow$ response

Operant conditionning: Skinner box The behaviour of the animal is shaped until the desired response is obtained

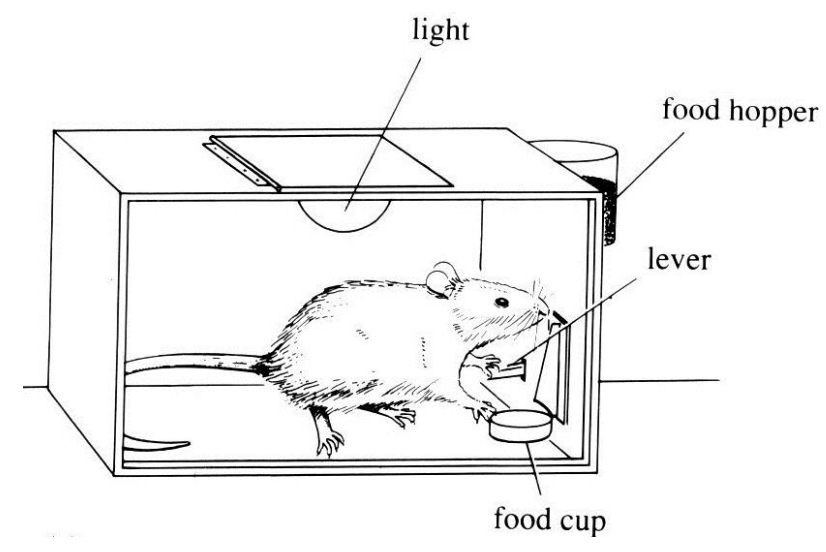

Behaviour: adaptive response of an organism to stimuli from the environment.

What happens in the black-box is impossible to study

\begin{tabular}{|c|c|c|}
\hline & $Q_{\text {Vortarm }}$ & $\begin{array}{l}\text { CARDIFF } \\
\text { UNIVERSITY }\end{array}$ \\
\hline 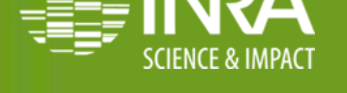 & A) VetAgrc & $\begin{array}{l}\text { PRRFYSCOL } \\
\text { CARDPY }\end{array}$ \\
\hline
\end{tabular}




\section{Zoology: ethology}

Observation of animals in their natural environment

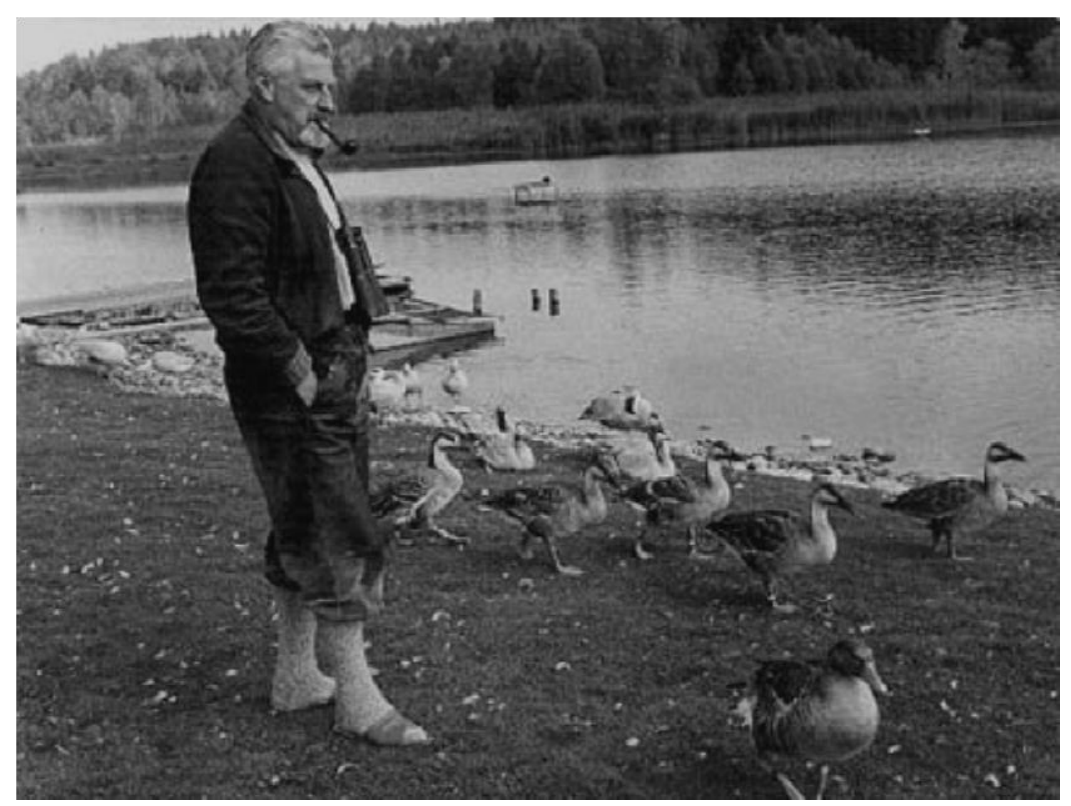

Lorenz

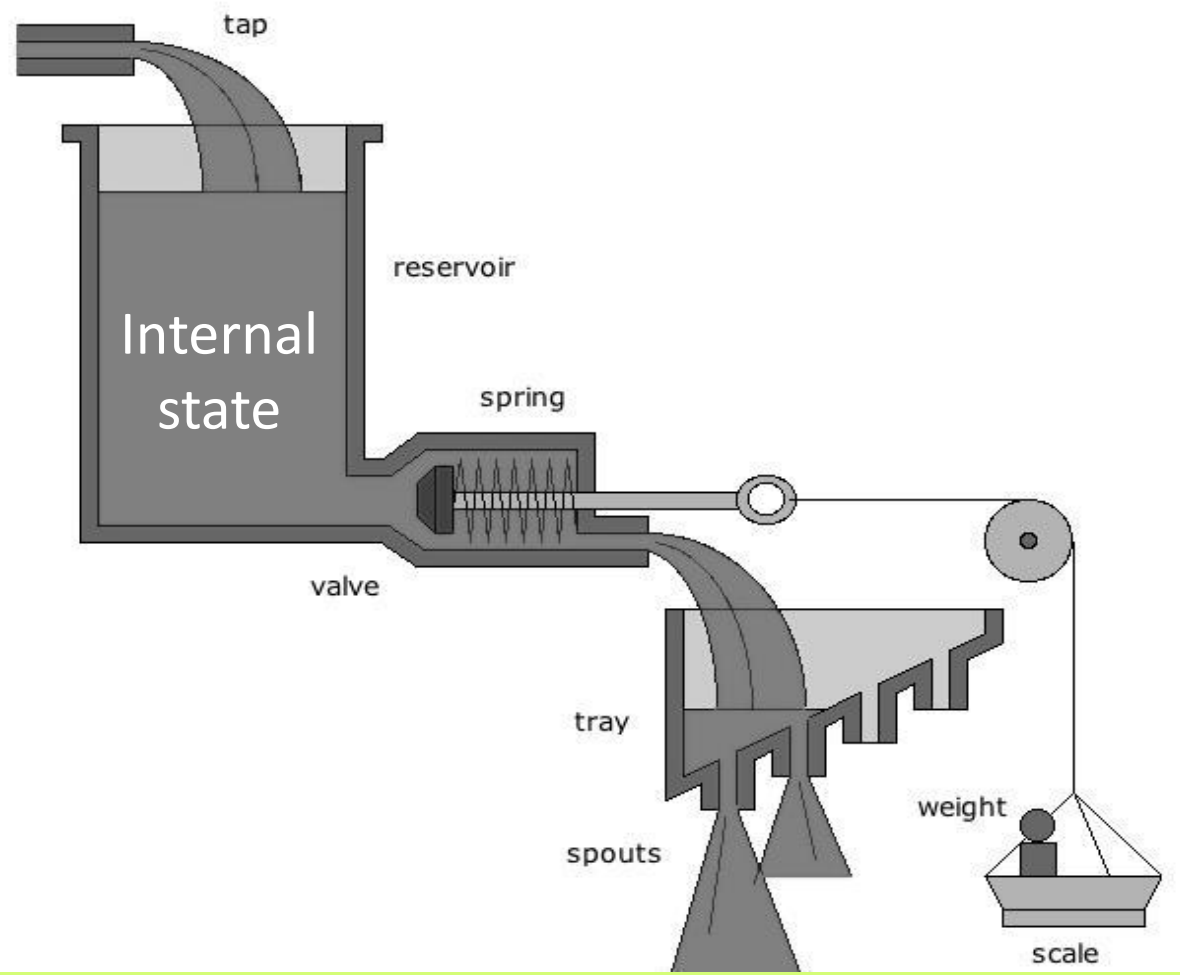

\section{Innate behaviours, behavioural repertoire} Importance of the internal state (motivation) Animal mind is again a black-box 


\section{Veterinary medicine}

Description of clinical signs

$\downarrow$

Identification of disorders

$\downarrow$

Understanding of pathogeny

$\downarrow$

Medical treatment

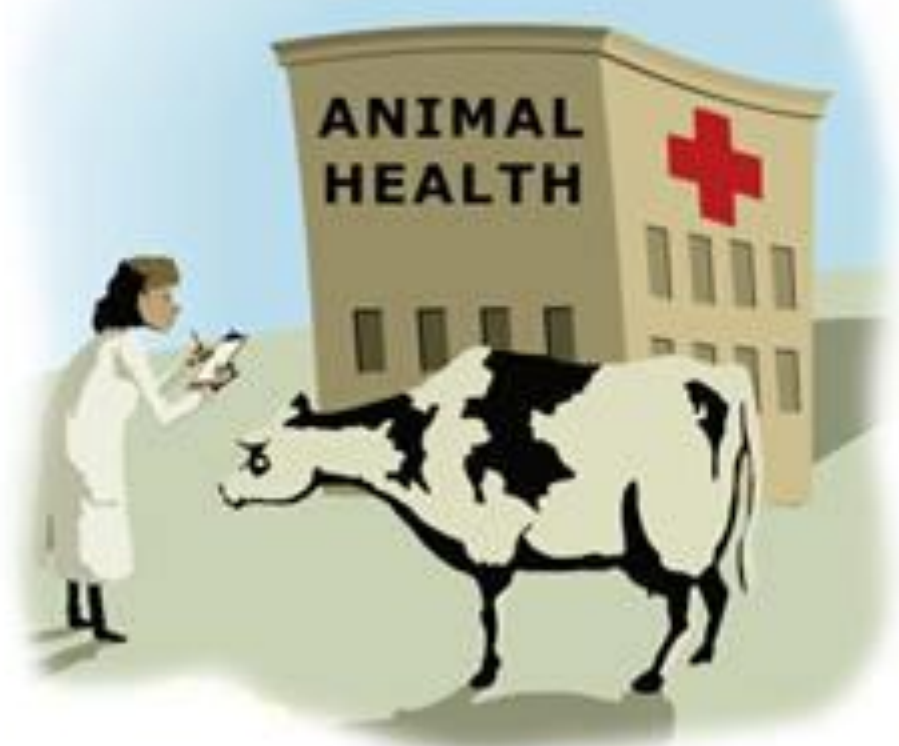

The disease is cured

What the animal feels is not taken into account 


\section{Early studies}

- In philosophy, mental states started to be attributed to animals

- Stress physiology, behaviourism, ethology, veterinary medicine: considered that mental states are not possible to study

- The word 'animal welfare' was not used 


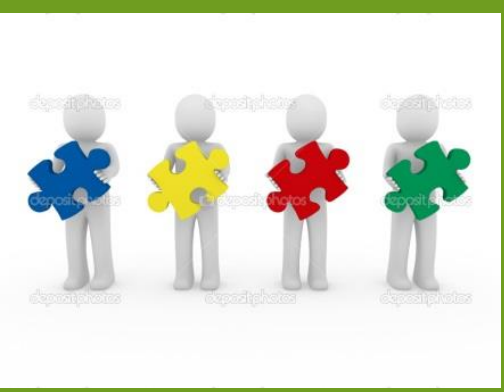

ANIMAL WELFARE BECOMING AN OBJECT OF RESEARCH Use of methods previously designed for other purposes 
Brambell report: We need to use scientific evidence available concerning the feelings of animals (1965)

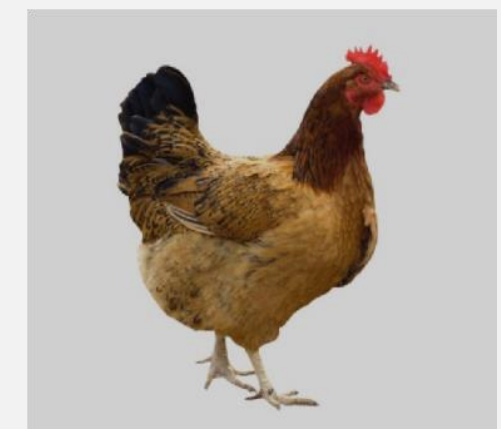

Flooring for hens

The views of humans (Brambell report 1965)
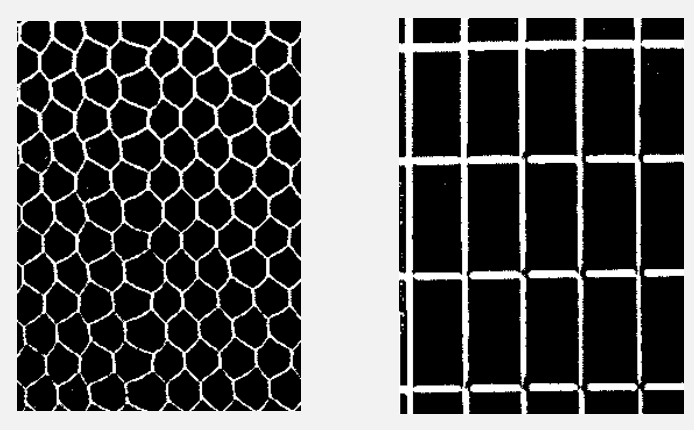

The views of hens (Hughes \& Black 1975)

$+$

(time spent on each floor, no. eggs)

The views of hens differ from that of humans! 


\section{The study of animals' preferences}

Use of operant conditioning: animals are required to work to obtain a reward or avoid a punishment

Readiness to work hen pushing door to access a nest

power on the door

$(\mathrm{N} / \mathrm{s})$

3500

3000

2500

2000

1500

1000

500

0

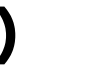




\section{Naturalistic approach}

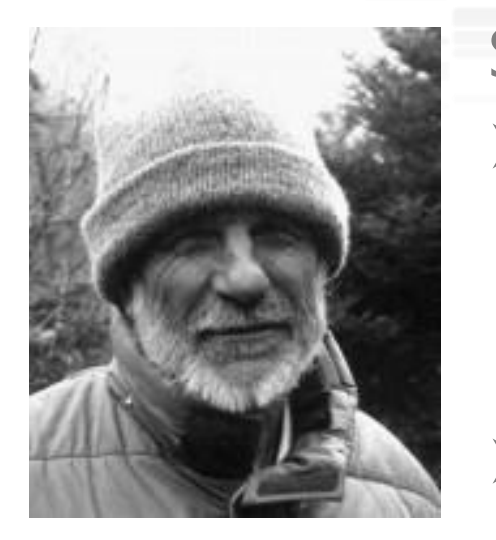

Stolba \& Wood-Gush 1984

$>$ Observations in natural

environment:

Identification of key features for pigs to express their behaviour

$>$ Reproduction in farm conditions

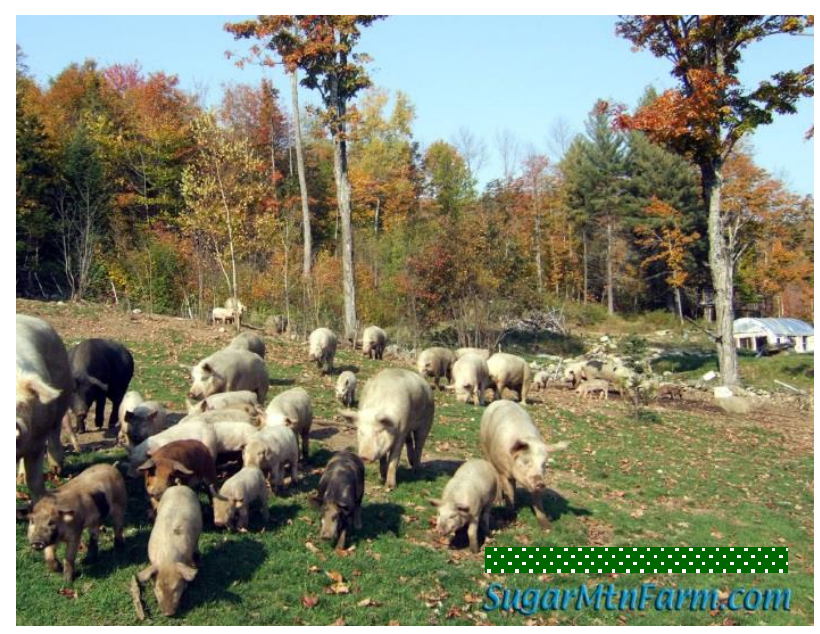

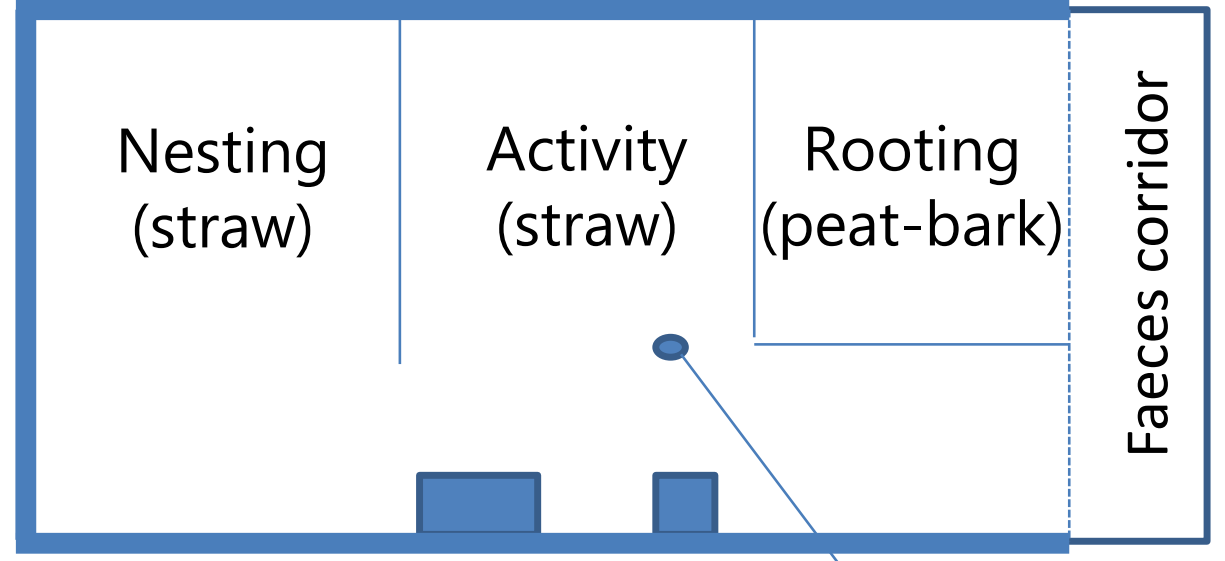

trough water rubbing post

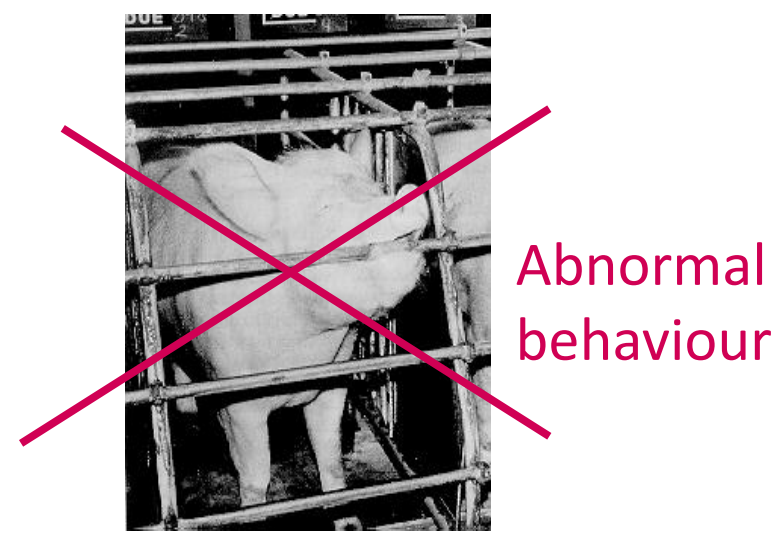

Welfare is improved Production is increased

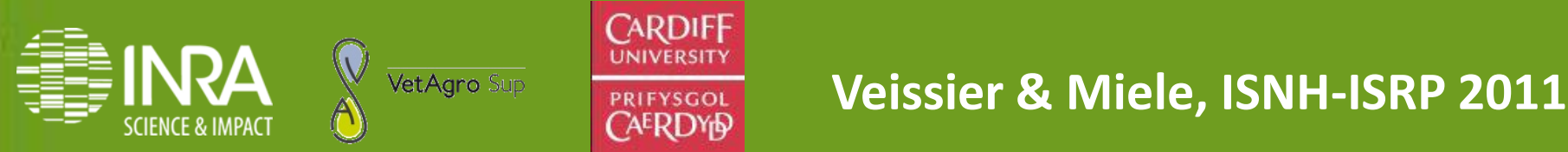




\section{Indices of poor welfare (stress responses)}

Gilts in 5 housing conditions
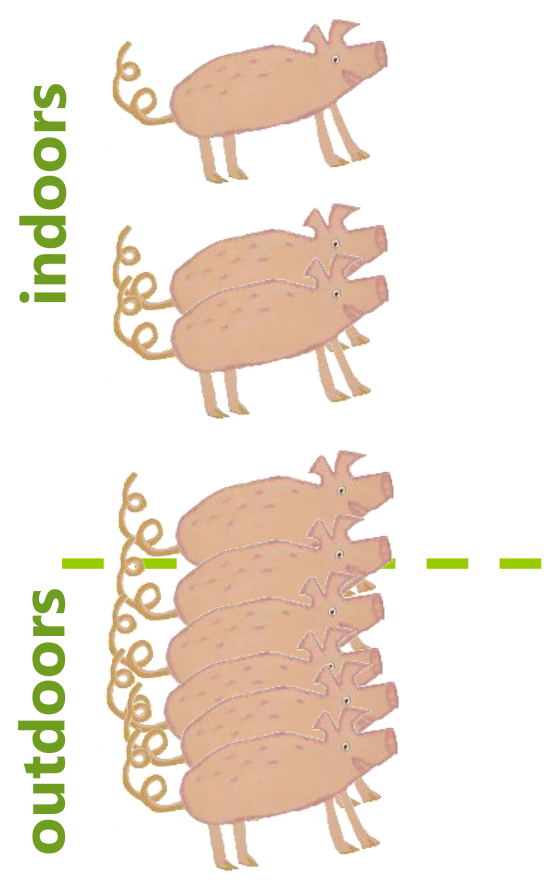

\begin{tabular}{|c|c|c|c|}
\hline Cortisol & $\begin{array}{c}\text { Abnormal } \\
\text { behaviour }\end{array}$ & $\begin{array}{l}\text { Champing } \\
\text { Biting }\end{array}$ \\
\hline
\end{tabular}

Stall + neck tether

Pair - pen $4 \mathrm{~m} \times 1.8 \mathrm{~m}$

Group - pen $4.1 \mathrm{~m} \times 3.5 \mathrm{~m}$

Group $15 \mathrm{~m} \times 15 \mathrm{~m}$

Group Paddock $41 \mathrm{~m} \times 17 \mathrm{~m}$
$3 \%$

3.6

$\pi \pi$

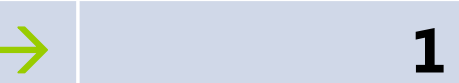

$\pi$

0.4

1

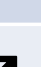

$\pi$

0.7

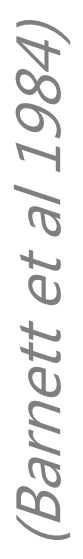

A prolonged rise in blood cortisol is a sign of poor welfare (Barnett and Hemsworth 1990) 


\section{Animal welfare: a science on its own}

\section{Fundamental questions in animal welfare science}

1. To what extent are the animals used by humans capable of emotions? In other words, what affective states can they feel?

2. How does an animal perceive its environment? In other words, what are the situations which are perceived negative vs. positive, or what are the elements animals like vs. dislike?

3. How can we assess the level of animal welfare in a given situation?

4. What are the impacts of the ways we treat animals (during their life or at slaughter) on the welfare of these animals?

5. What recommendations can we make as to improve animal welfare?

(Veissier \& Forkman 2008) 


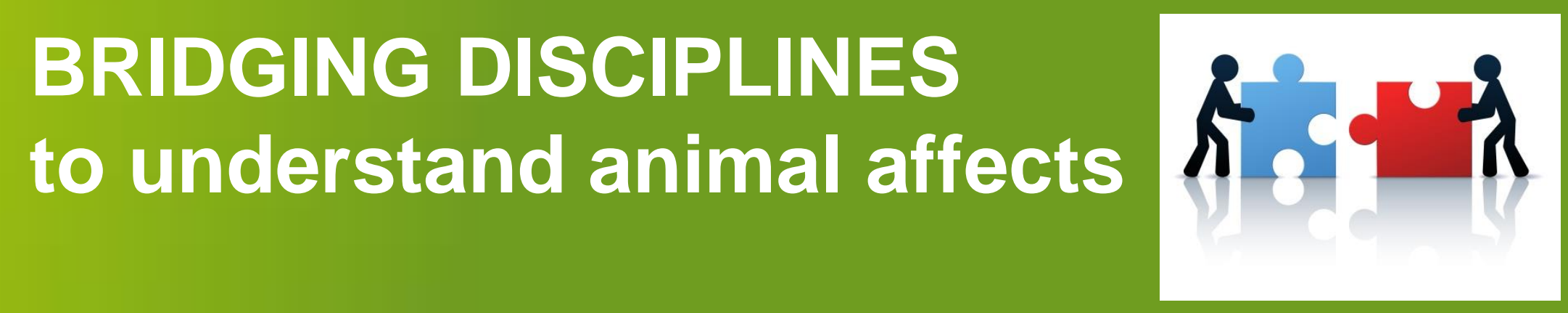




\section{The stress concept refined}

Mason 1971

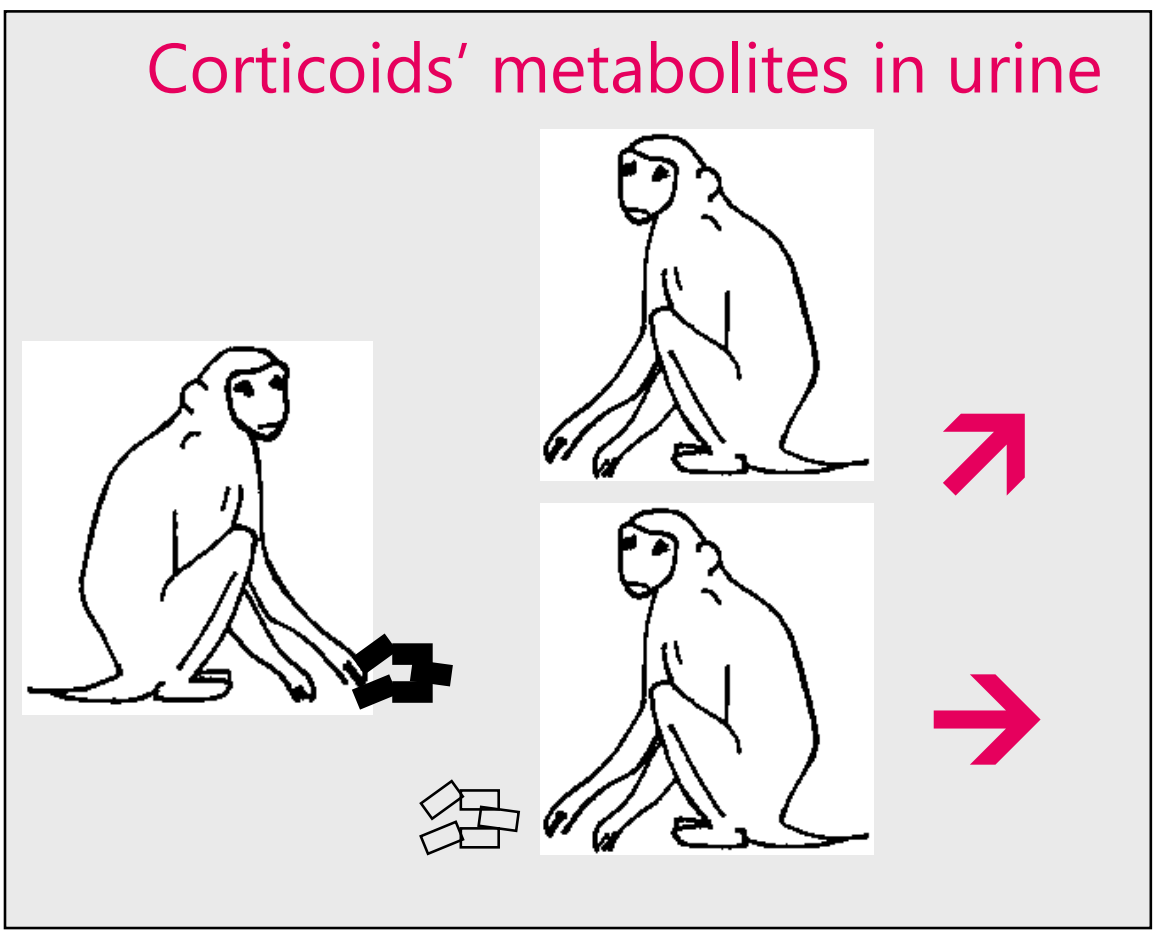

Fastening stresses monkeys only if they are aware of it

The un-specificity of stress responses comes from the common emotion that triggers them

Psychology helps understand physiological reactions 


\section{The study of emotions (1/4)}

$\checkmark$ Cognitive psychology

An emotion is triggered by the evaluation of the situation according to a series of checks (Lazarus 1984, Scherer 1999)

1 .
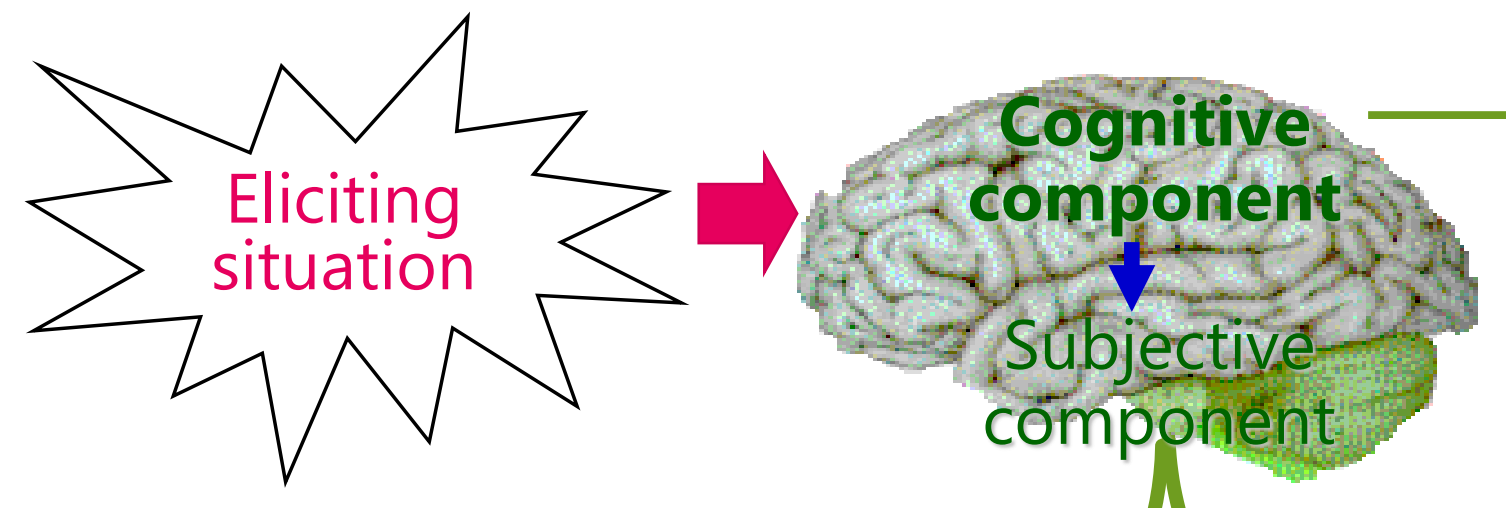

Suddenness

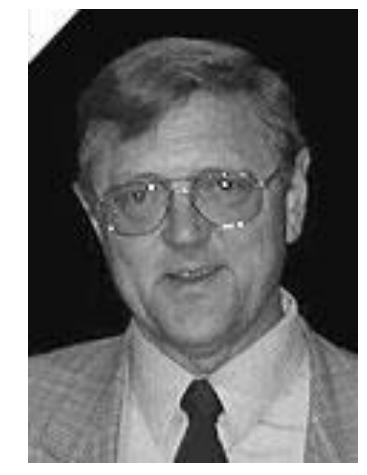

Behavioural component (e.g. facial expression, startle)

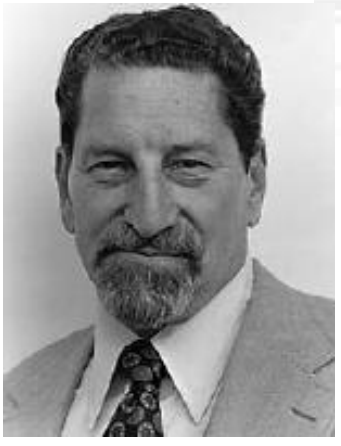
(1) 


\section{The study of emotions (2/4)}

Checks

\begin{tabular}{|l|l|l|l|l|l|l|l|l|l|}
\hline Suddenness & High & $\mathrm{H}$ & $\mathrm{L}$ & $\mathrm{H}$ & $\mathrm{VL}$ & $\mathrm{L}$ & & $\mathrm{L}$ & \\
\hline Familiarity & Low & $\mathrm{L}$ & & $\mathrm{VL}$ & $\mathrm{H}$ & & & & $\mathrm{L}$ \\
\hline Predictable & $\mathrm{L}$ & $\mathrm{L}$ & Medium & $\mathrm{L}$ & $\mathrm{VH}$ & $\mathrm{M}$ & & & $\mathrm{L}$ \\
\hline Pleasantness & $\mathrm{L}$ & open & & & & $\mathrm{VH}$ & & & $\mathrm{VL}$ \\
\hline $\begin{array}{l}\text { Consistent to } \\
\text { expectation }\end{array}$ & $\mathrm{L}$ & $\mathrm{L}$ & & $\mathrm{VL}$ & $\mathrm{H}$ & $\mathrm{H}$ & & & \\
\hline Control & $\mathrm{L}$ & $\mathrm{H}$ & $\mathrm{H}$ & $\mathrm{VL}$ & $\mathrm{M}$ & & & & \\
\hline Social norms & $\mathrm{V}$ & $\mathrm{L}$ & $\mathrm{L}$ & & & & $\mathrm{H}$ & $\mathrm{L}$ & \\
\hline Emotion & Fear & Rage & Anger & $\begin{array}{l}\text { Des } \\
\text { pair }\end{array}$ & $\begin{array}{l}\text { Bore } \\
\text { dom }\end{array}$ & $\begin{array}{l}\text { Happi } \\
\text { ness }\end{array}$ & Pride & Shame & Disgust \\
\hline
\end{tabular}

\section{(Sanders et al., 2005)}




\section{The use of appraisal theories to study sheep}

\section{Ex: Relevance of the check Predictability}

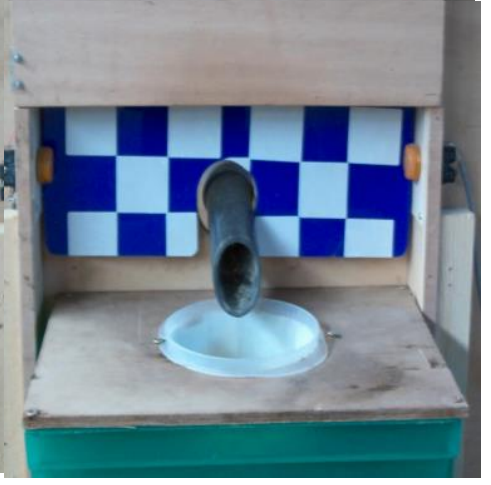

at random

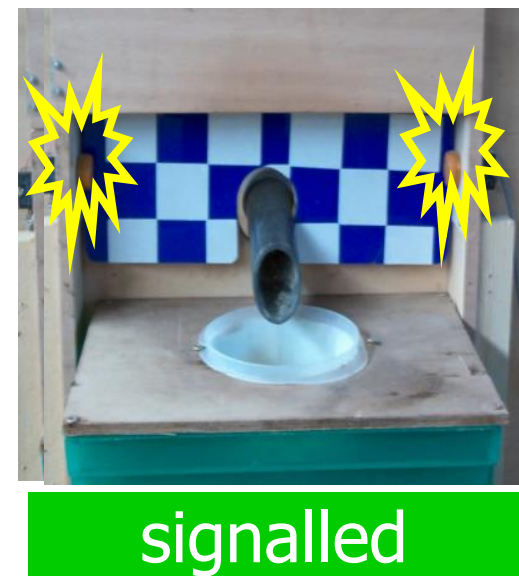

$=1 \mathbb{N}$

\section{Experimental paradigm}

Lamb eating concentrates

Object falling suddenly behind the trough

The fall is preceded or not by a light signal
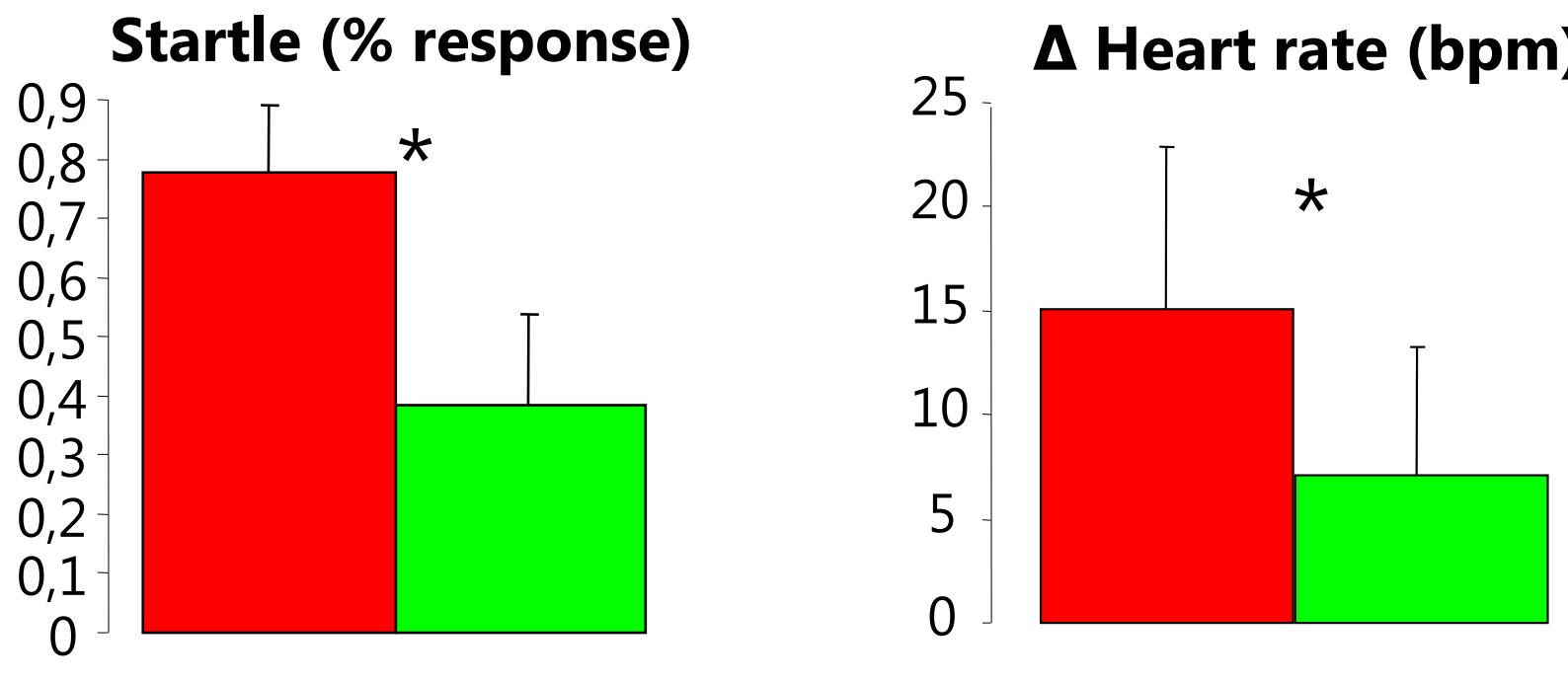


\section{Sheep emotions (4/4)}

Checks Outcome of checks experimentally manipulated

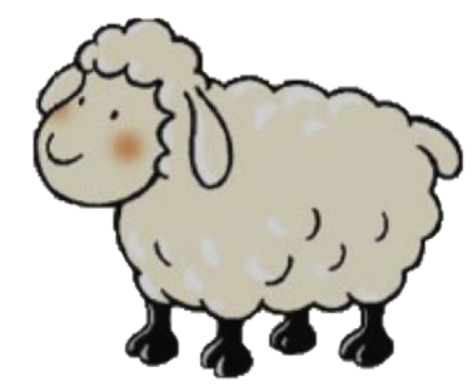

\begin{tabular}{|l|l|l|l|l|l|l|l|l|l|}
\hline Suddenness & High & H & Low & H & VL & L & & L & \\
\hline Familiarity & L & L & & VL & H & & & & L \\
\hline Predictable & L & L & Medium & L & VH & M & & & L \\
\hline Pleasantness & L & & & & & VH & & & VL \\
\hline $\begin{array}{l}\text { Consistent to } \\
\text { expectation }\end{array}$ & L & L & & VL & H & H & & & \\
\hline Control & L & H & H & VL & M & & & & \\
\hline Social norms & & L & L & & & & H & L & \\
\hline Emotion & Fear & Rage & Anger & $\begin{array}{l}\text { Des } \\
\text { pair }\end{array}$ & $\begin{array}{l}\text { Bore } \\
\text { dom }\end{array}$ & $\begin{array}{l}\text { Happi } \\
\text { ness }\end{array}$ & Pride & Shame & Disgust \\
\hline
\end{tabular}




\section{Affective states and diseases}

Force-swimming test:

when ill

mice move more

Stressful event but stop moving earlier
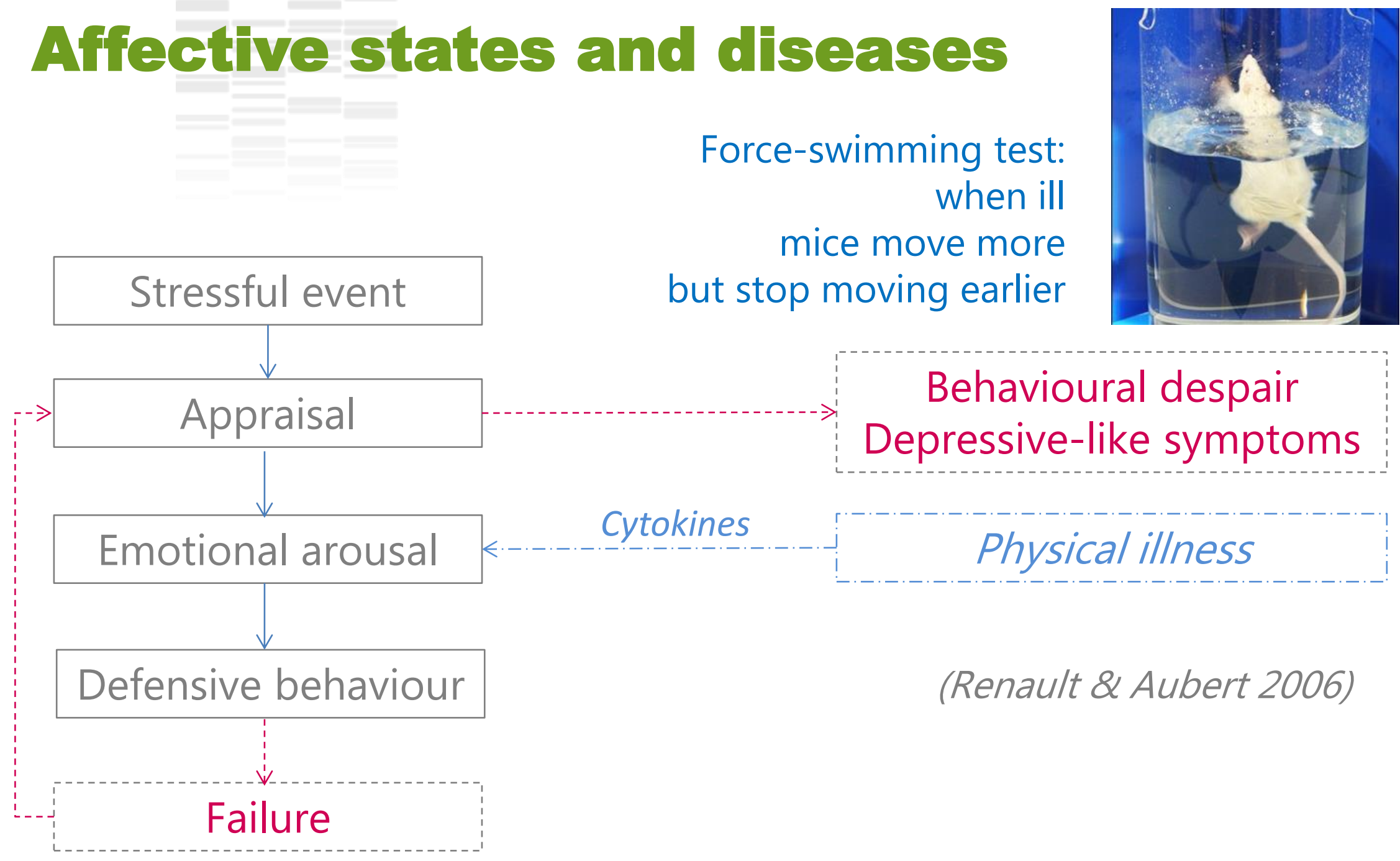

Behavioural despair Depressive-like symptoms

Cytokines

Physical illness

(Renault \& Aubert 2006)

\section{Health helps understand behaviour $\&$ vice versa}




\section{Behaviour \\ Physiology}

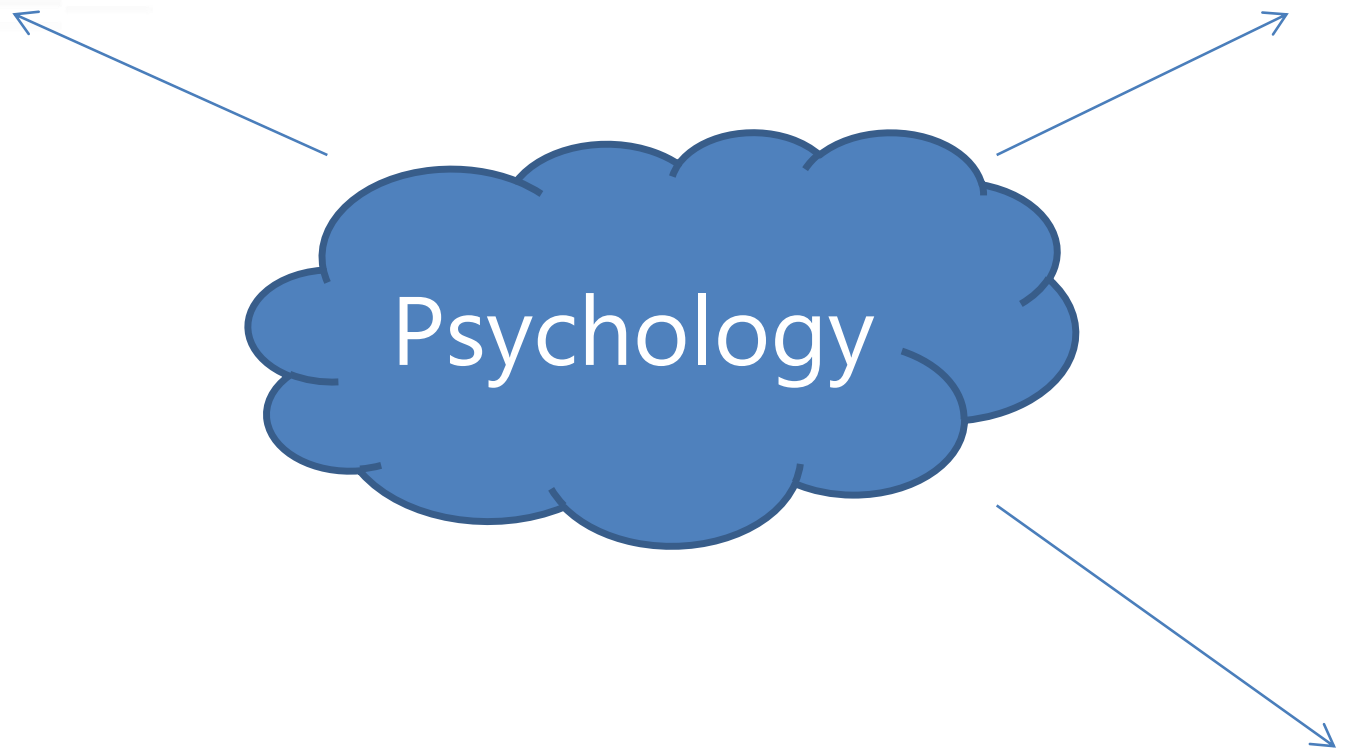

Health

\section{Disciplines need to talk to each other}




\section{INTERDISCIPLINARY STUDIES to develop a welfare assessment system}

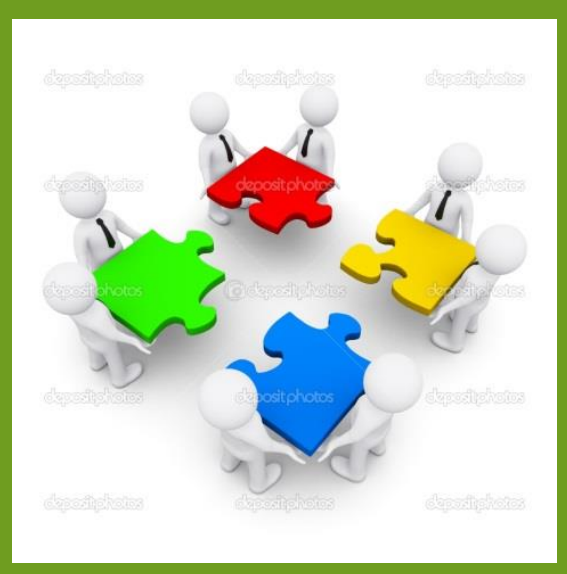




\section{Welfare Quality ${ }^{\circledR}$ project in}

- 2004-2009, 40 partners

- One core objective: to design an on-farm welfare assessment system for cattle, pigs, poultry
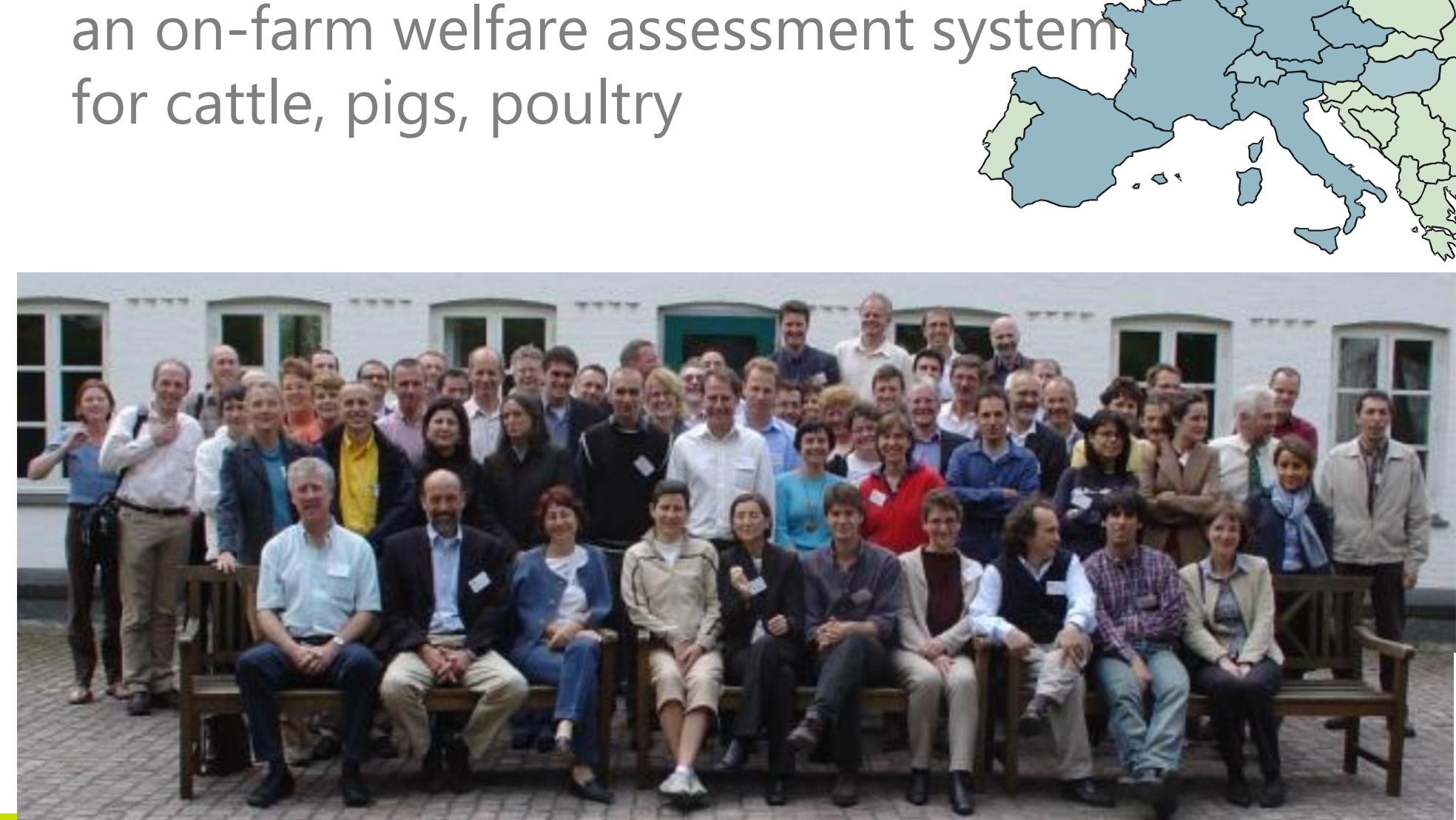

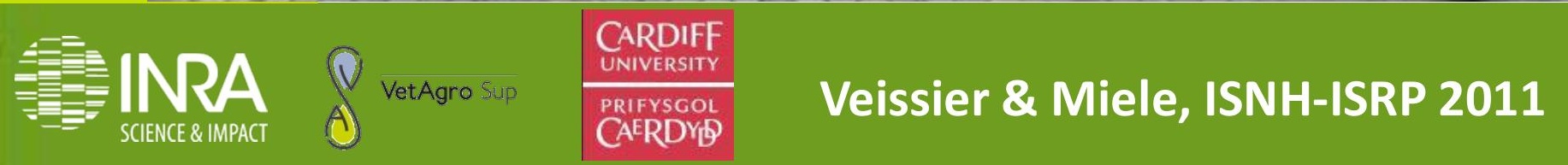

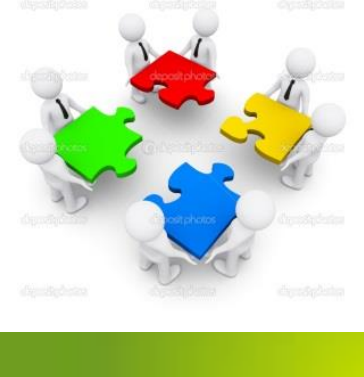




\section{Interdisciplinarity in Welfare Quality ${ }^{\circledR}$}

\section{Initial organisation}

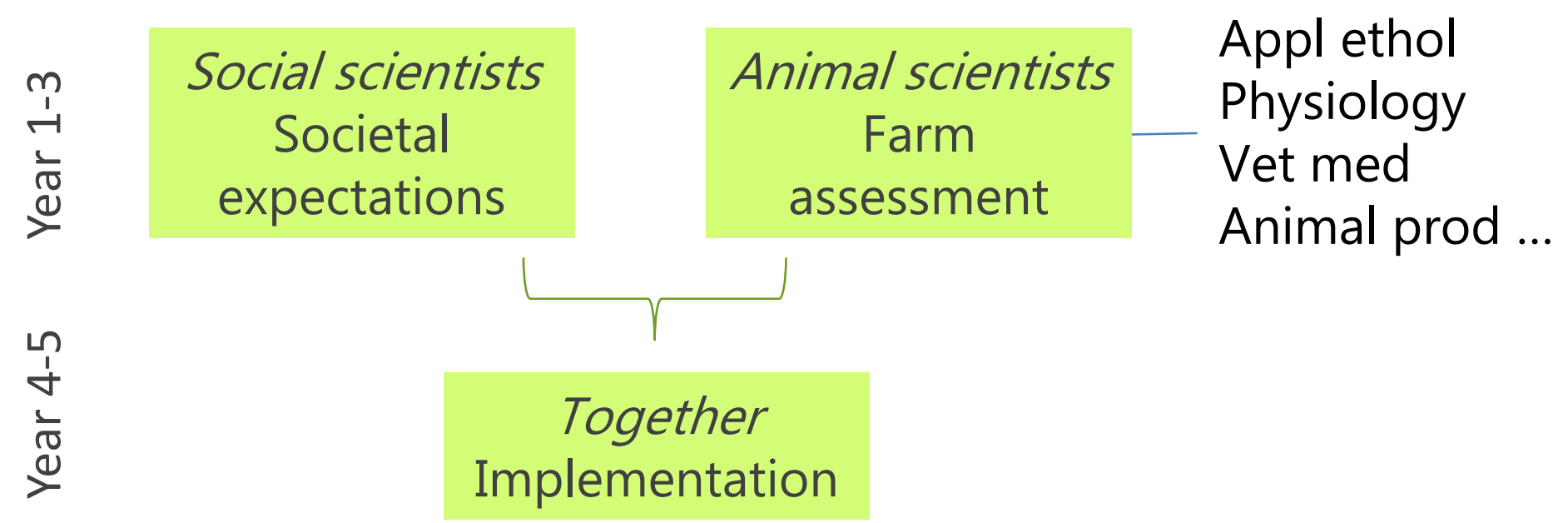

Steps

1. Definition of welfare dimensions

2. Definition of welfare measures

3. Design of a scoring model 


\section{Step 1: welfare dimensions to be covered}

\section{Principles Criteria}

Good feeding 1 . Absence of prolonged hunger

- 2. 2 Absence of prolonged thirst

3. Comfort around resting

Good housing 4 . Thermal comfort

5. Ease of movement

6. Absence of injuries

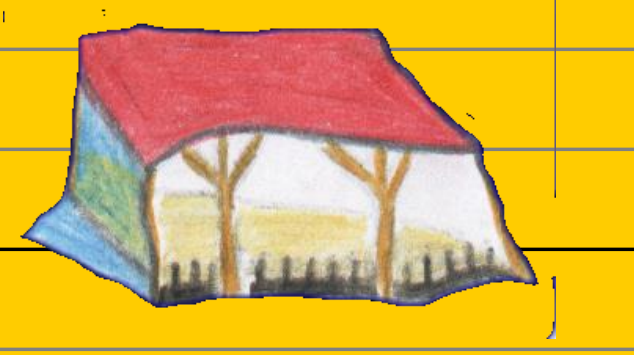

Good health

7. Absence of disease

8. Absence of pain induced by management procedures

9. Expression of social behaviours

Appropriate

10. Expression of other behaviours

behaviour

11. Good human-animal relationship

12. Positive emotional state

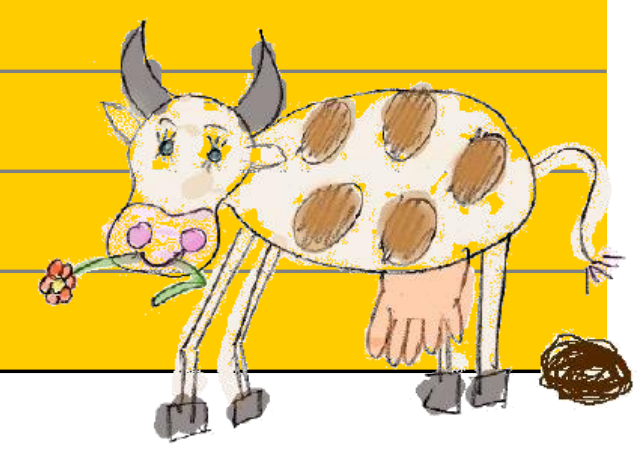


Step 2: Definition of welfare measures (priority is given to measures on animals)

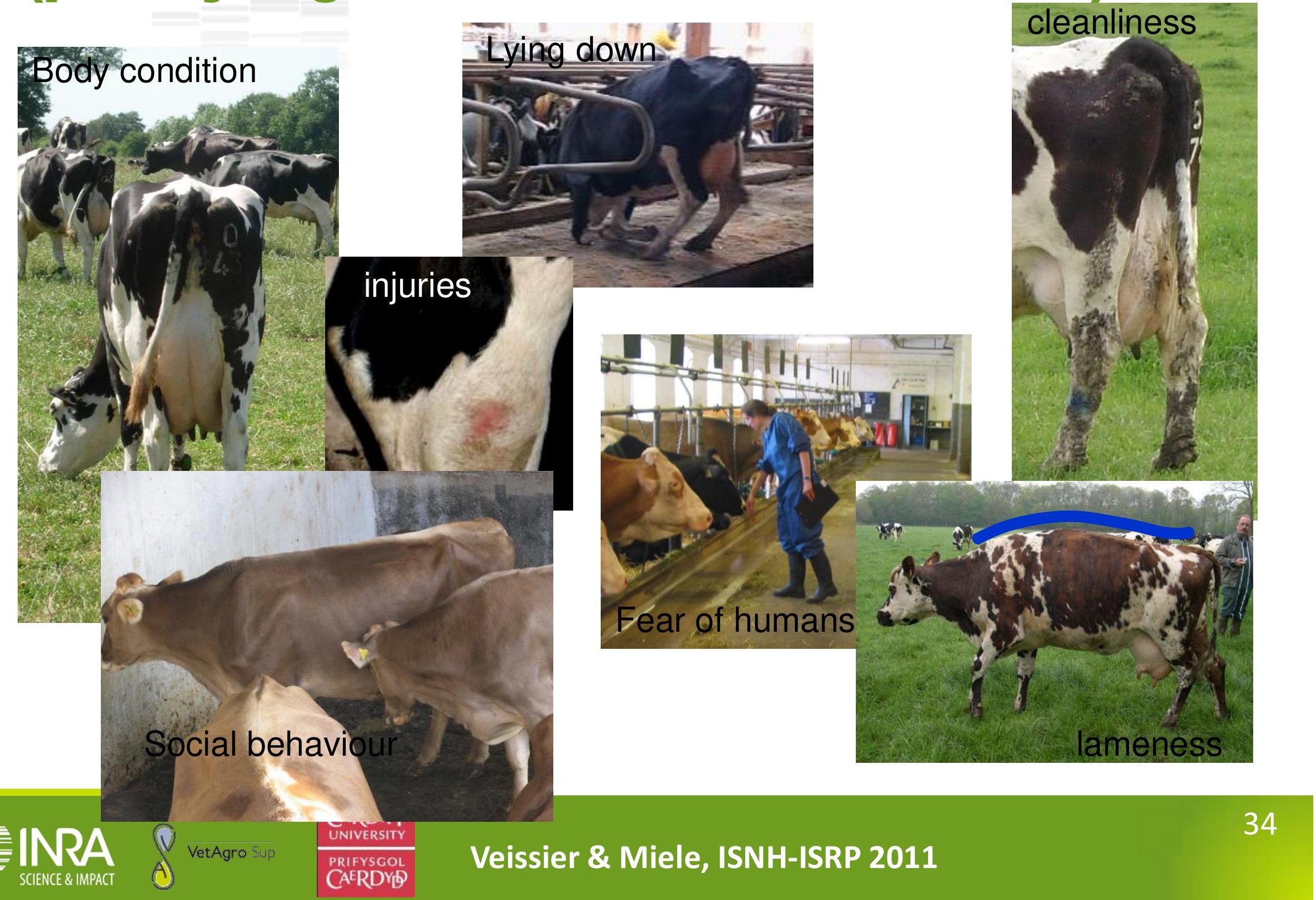




\section{Step 3: Design of a scoring model}

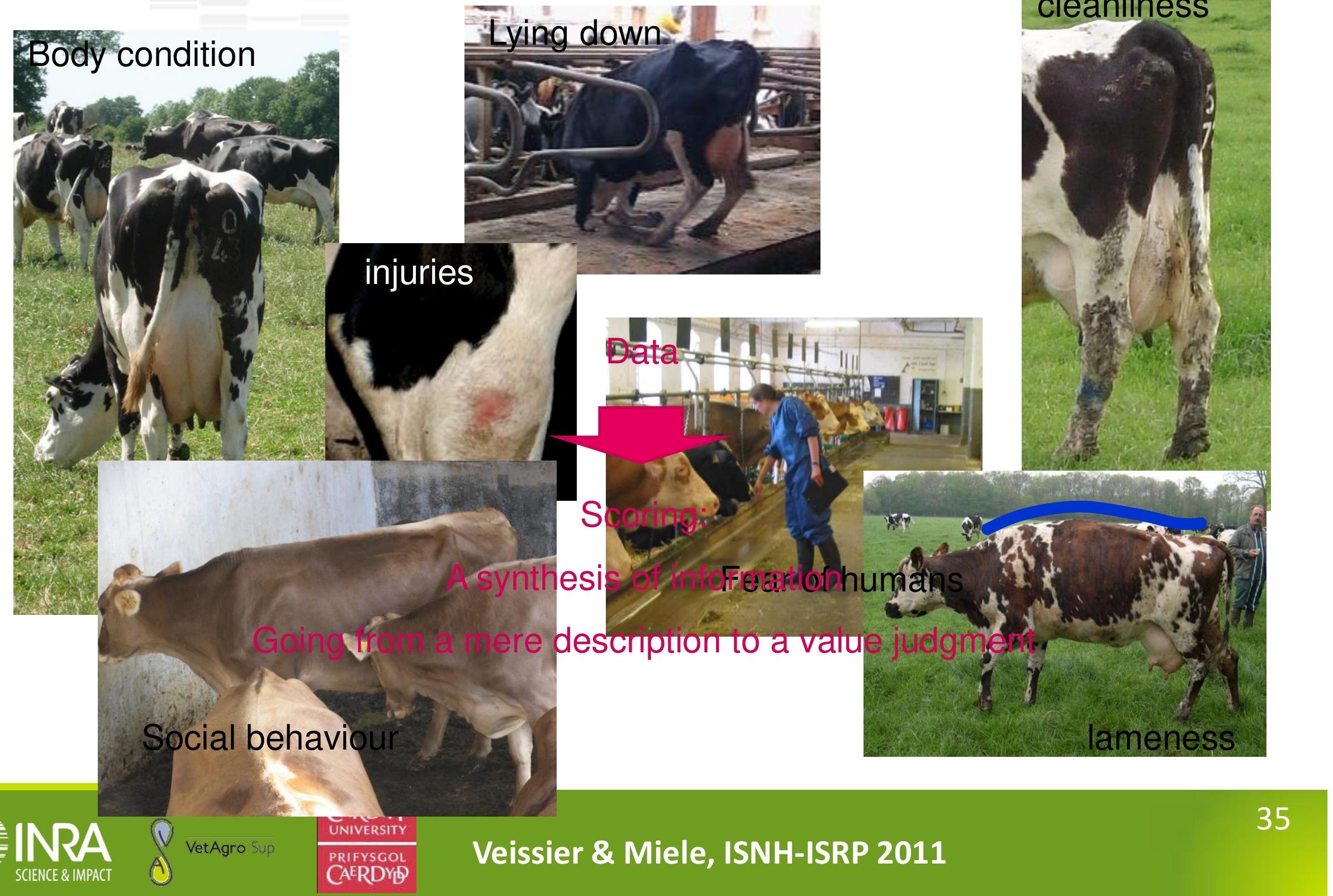




\section{Value-based questions}

1- Shall we consider the average state of animals in a herd vs. put more attention on the worse animals?

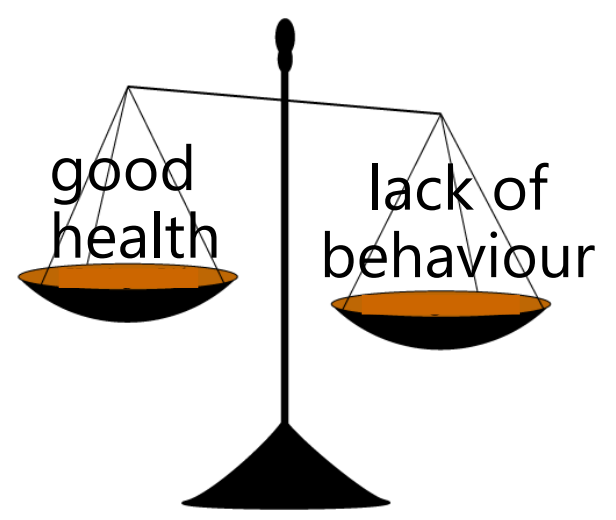

2- Can one aspect of welfare compensate for another?

3- Shall the judgement be based on what seems good welfare in theory or on what can realistically be achieved in practice?
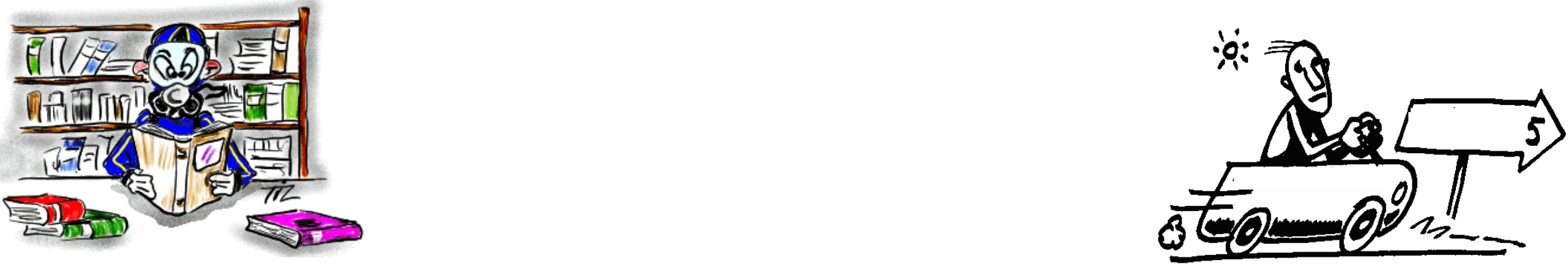


\section{Interdisciplinarity in Welfare Quality ${ }^{\circledR}$}

Final organisation

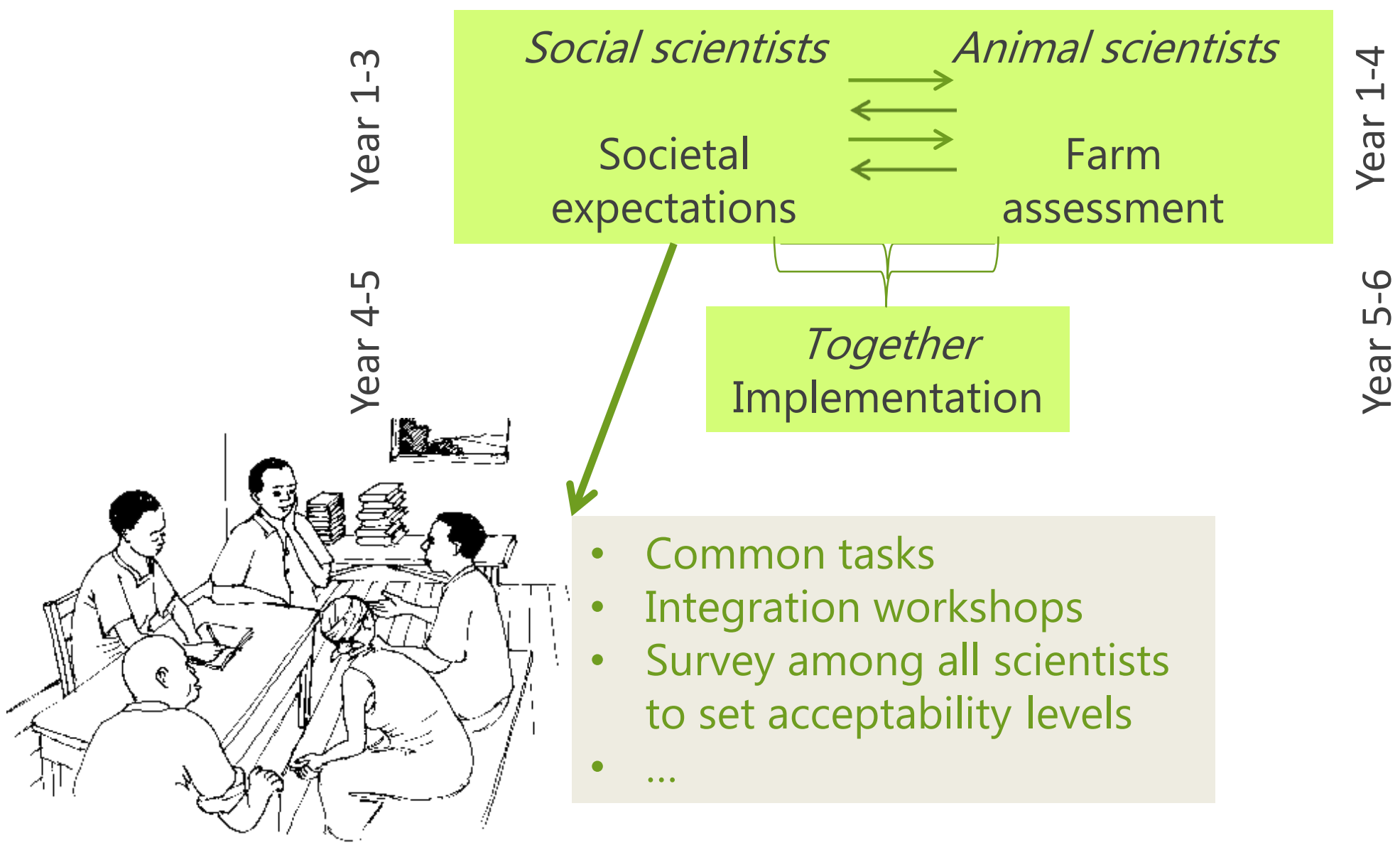




\section{Interactions between scientists and society to design the welfare assessment system in Welfare Quality ${ }^{\circledR}$}

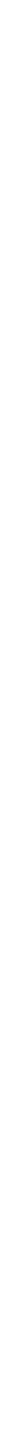




\section{What did we gain from these interactions?}

Naturalness is put forward by citizens

$>$ Access to pasture was added for cattle

Citizens want to go beyond absence of suffering

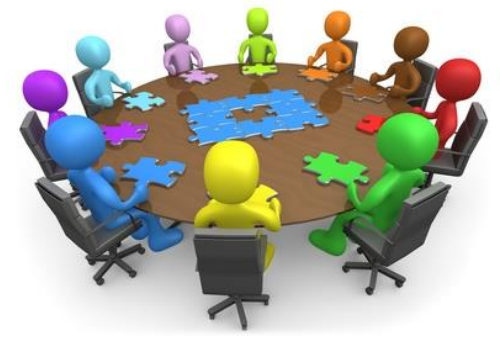

$>$ Investigation of measures of positive affects

Values underlying the scoring system were made clear

$>$ The animals in poor states are given priority

$>$ Some criteria are given more importance (thirst > hunger)

$>$ Little compensation between criteria

$>$ Overall assessment based on theoretical objectives and pragmatic rules

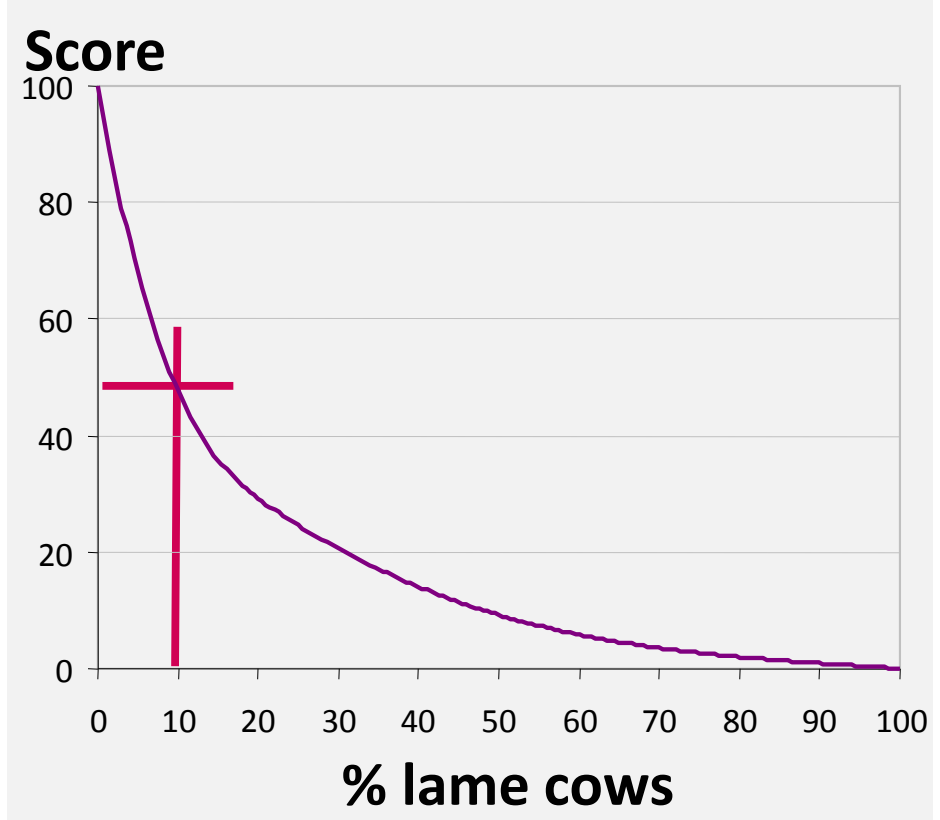


FINAL WORDS

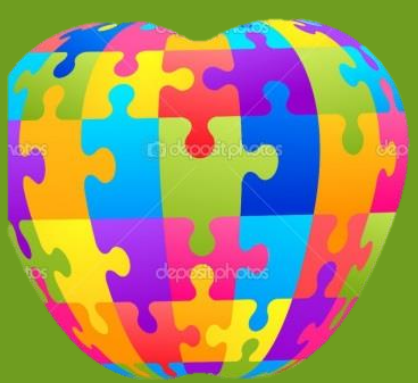




\section{A mandated science}

Our understanding of animal welfare is both values-based and science-based. [...] animal welfare is like many other topics of "mandated" science such as food safety and environmental sustainability where the tools of science are used within a framework of values (Fraser 2008)

$>$ Assessing animal welfare requires a transdisciplinary approach where scientists from various disciplines - specially animal and social scientists - work together and with society

$>$ People need to discuss both facts and values

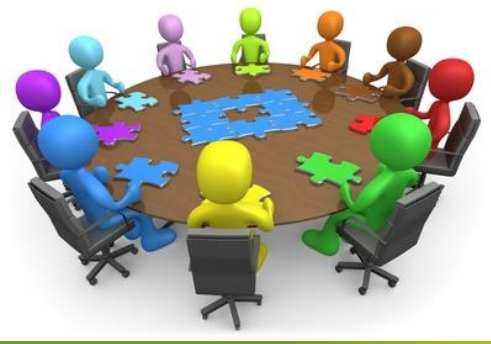




\section{Transdisciplinarity}

'a specific form of interdisciplinarity in which boundaries between and beyond disciplines are transcended and knowledge and perspectives for different scientific disciplines as well as nonscientific sources are integrated'

(Flinterman et al 2011)

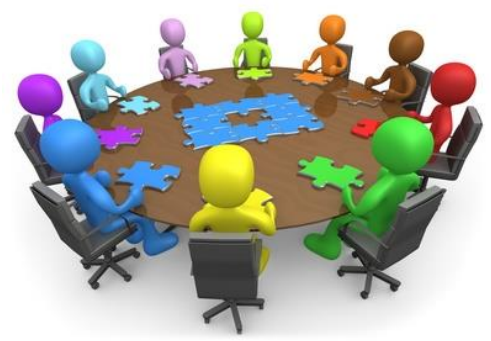




\section{Further steps towards transdiciplinarity}

- Scientists should be ready to

- quit their disciplinary home,

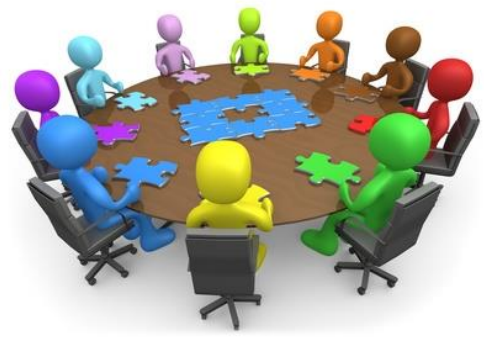
at least for the time of a project

- try to reason with the framework of other disciplines

- engage in common tasks with scientists from other disciplines and non-scientists

- Researches should be evaluated not only on publications (usually within disciplines) but also on impacts 
Early studies: separate disciplines, animal welfare not directly addressed

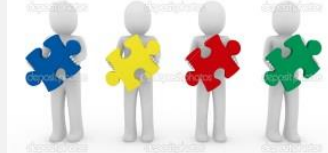

Animal welfare becoming an object of research use of methods previously designed

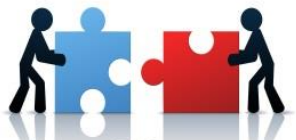

Bridging disciplines to understand animal affects

Interdisciplinary approach to develop a welfare assessment system

Next step: Transdiciplinarity to address facts $\&$ values

\section{For a complete picture of animal welfare}

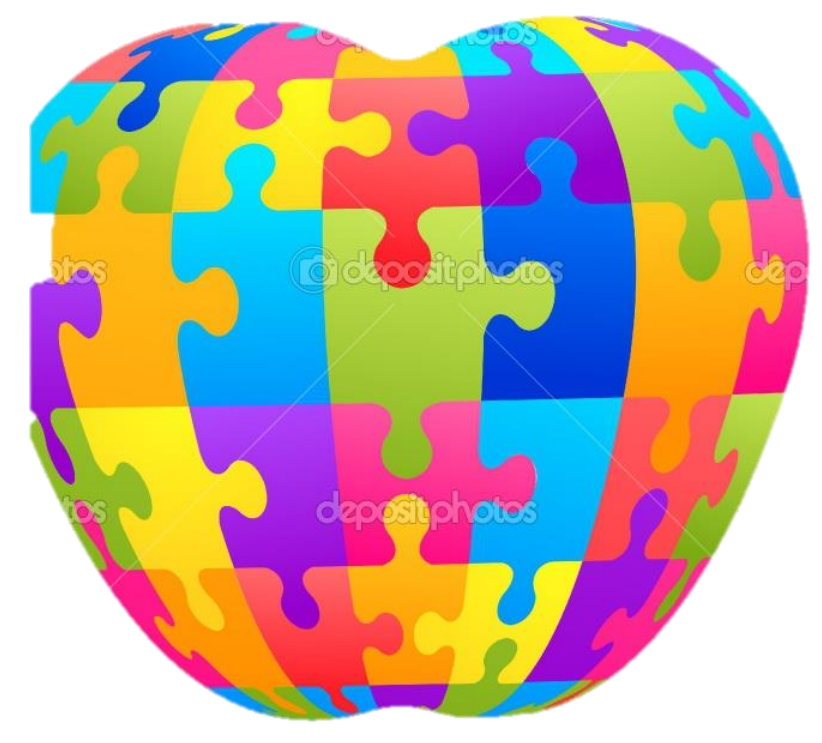

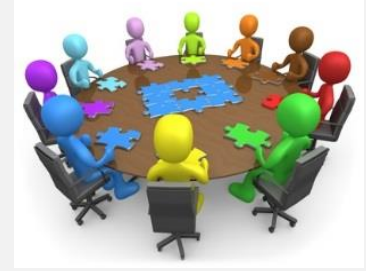




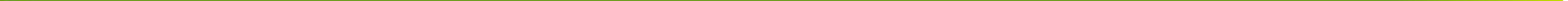

